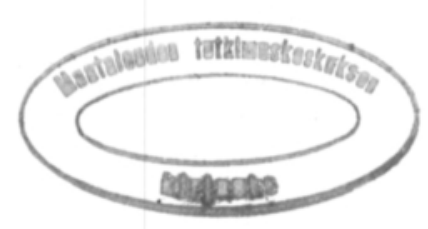

\title{
RAINBOW TROUT (SALMO IRIDEUS) PRODUCED IN FINLAND \\ III. Seasonal variations in rainbow trout
}

\author{
Jorma J. Laine, Elina Varesmaa \& Fritz P. Ninnivaara \\ University of Helsinki, Institute of Meat Technology
}

Received April 14, 1967

Seasonal variations in fish are complex and dependent on many factors. The Atlantic sardine e.g. contains $2 \%$ of lipids in the spring and over $8 \%$ in the fall (JAcQUOT, 1961). There can also be remarkable changes in the protein content in this same species, namely $16 \%$ in March and $20.6 \%$ in July (DeL Riego 1948).

Investigations on cultivated fish reveal big seasonal changes. According to JACQUOT (1961), with improved dietary conditions the percentage of edible parts in cultivated carp increases from 55 to $67 \%$, the lipid content from 0.4 to $4.9 \%$, and the protein from 14.8 to $19.5 \%$.

The seasonal changes in the growth, the chemical composition, and the microbiological and organoleptic qualities of rainbow trout (Salmo irideus) produced in Finland were studied in the present work. Changes in the chemical and microbiological qualities of the cultivating waters were followed.

\section{Material and methods}

Experiments were carried out with 2-year old trout cultivated in four geographically different places of growth (I), (II), (III), and (IV) (Fig. 1). The sampling days were May 11th, July 18th, September 26th in 1966, and February 2nd in 1967. Except on the last sampling day all the fish were taken alive into the laboratory. Each sample consisted of six individual fishes. At the same time samples of the cultivating waters were collected into sterilized bottles. Each sample consisted of $500 \mathrm{ml}$ of water.

In the laboratory the fish was killed and weighed. Before weighing microbiological samples were taken. In this case, the amount of the microbiological sample was added to the weight of the fish. Gutted weights were taken from the fish used in organoleptic evaluation, in the chemical analyses of gutted fish and from the fish used in microbiological analyses.

Chemical analyses were carried out with whole and with gutted fish. In both cases the fishes were first ground and then homogenized. From the homog- 


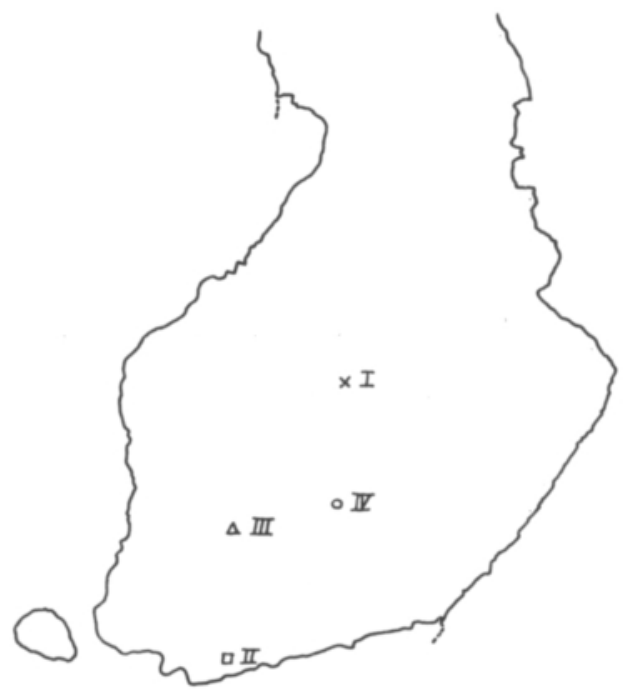

Fig. 1. Geographical situation of the four sampling places.

enized sample the following determinations were made: $\mathrm{pH}$, water content (AOAC 1965), fat content (POHJA et al., 1956), protein content (Cocks and VAN REDE, 1966), and ash content (AOAC, 1965).

Straight samples from the water samples were taken and the following determinations were made: $\mathrm{pH}$, total hardness, color, iron, and $\mathrm{KMnO}_{4}{ }^{-}$ consumption (HAASE 1954).

Microbiological samples were taken from the dorsal side of the fish (skin and flesh) and from the ventral side of the fish (skin, fins, and intestines). Samples from the dorsal side are considered as gutted fish and those of ventral side as whole fish. For each sample 11 grams of fish was aseptically weighed in $99 \mathrm{ml}$ of $0.9 \% \mathrm{NaCl}$-solution. The sample was then homogenized and the necessary decimal dilution series was prepared. Samples were tested for total viable counts on SPC-agar (Orion) and for total coliforms on VRB-agar (Orion) and using the MPNtechnique (American Public Health Association, 1958). Incubation was the same as in the previous study (NirnivaARA et al., 1966).

The same microbiological determinations were made from the water samples as from the fish.

The organoleptic evaluation was made by the same methods and with the same taste panel as in the previous study (NIINIVAaRA et al., 1966).

\section{Results}

Differences in weights between the sampling points depended upon the type of operation and food used. Number II was an experiment station and the fish were fed with natural food. In the cases of I, III and IV, the enterprises were commercial fish producers using high energy foods. However, in the IVth case efficient feeding was stopped at the end of the summer and the fish were not sold until the following year. This commercial point of view interfered somewhat with the experiment. 
Table 1. Mean weights of the whole fish $(\mathrm{g})$. In brachets the percentile part of the gutted trout (=considered edible proportion of trout).

Place of growth
Date
I
II
III
IV

\begin{tabular}{|c|c|c|c|c|c|c|c|c|c|}
\hline & • & g. & $\%$ & g. & $\%$ & g. & $\%$ & g. & $\%$ \\
\hline May & 11 & 227 & $(93.0)$ & 301 & (88.9) & 341 & $(87.8)$ & 186 & $(89.3)$ \\
\hline July & 18 & 200 & (89.8) & 333 & (84.8) & 495 & (83.4) & 242 & (88.6) \\
\hline Sept. & 26 & 217 & (82.9) & 384 & $(80.5)$ & 723 & (81.8) & 194 & (81.3) \\
\hline Febr. & 2 & 260 & $(83.0)$ & 348 & (85.9) & 760 & $(80.5)$ & 250 & $(84.5)$ \\
\hline
\end{tabular}

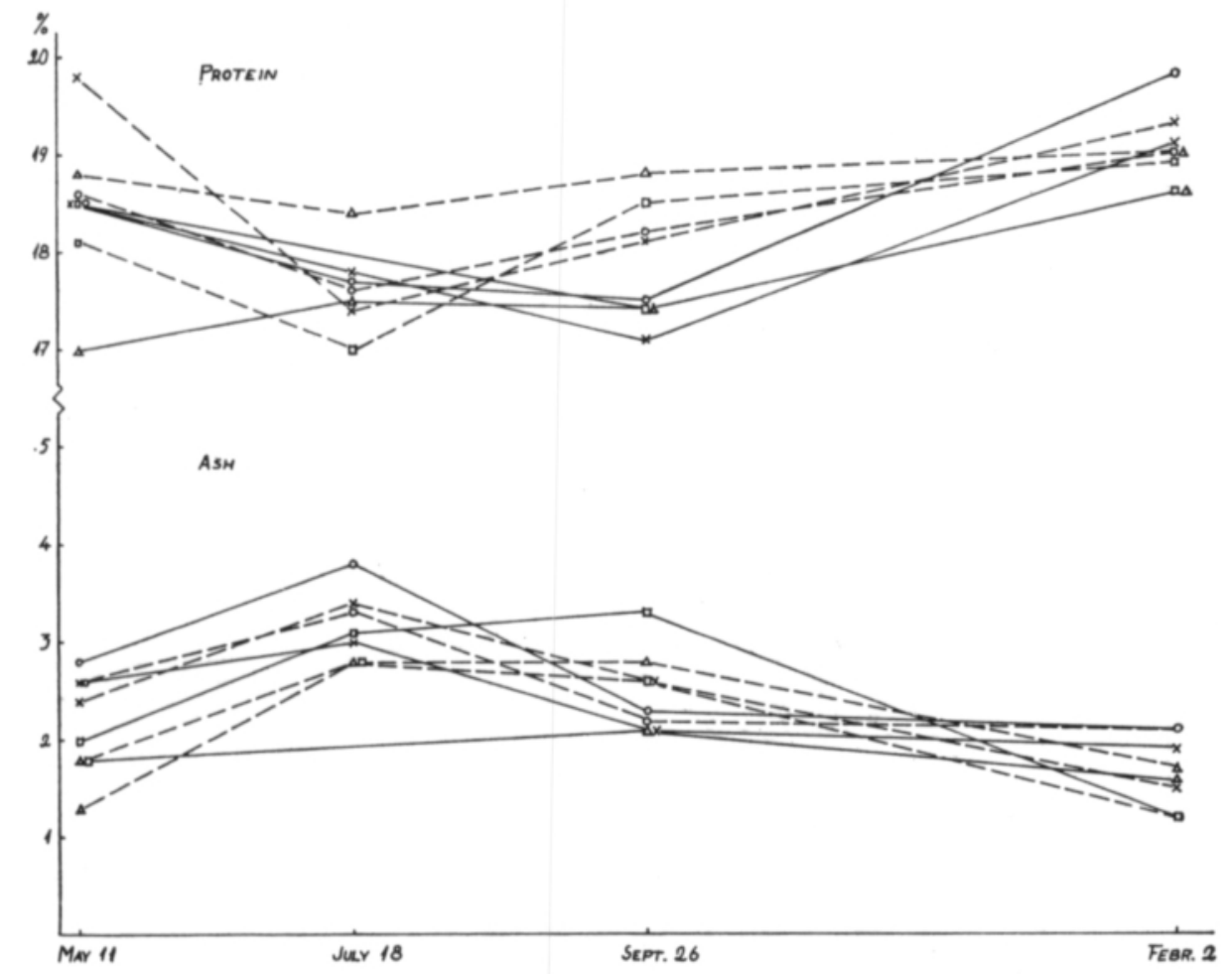

Fig. 2. Results of the approximate chemical analyses of fish.

Protein and ash contents.

$$
\begin{array}{cc}
\times-\times & \text { I, whole fish } \\
\times---\times & \text { I, gutted fish } \\
\square-\square & \text { II, whole fish } \\
\square---\square & \text { II, gutted fish } \\
\Delta-\triangle & \text { III, whole fish } \\
\Delta---\Delta & \text { III, gutted fish } \\
\text { O- } & \text { IV, whole fish } \\
\text { O- }-O & \text { IV, gutted fish }
\end{array}
$$




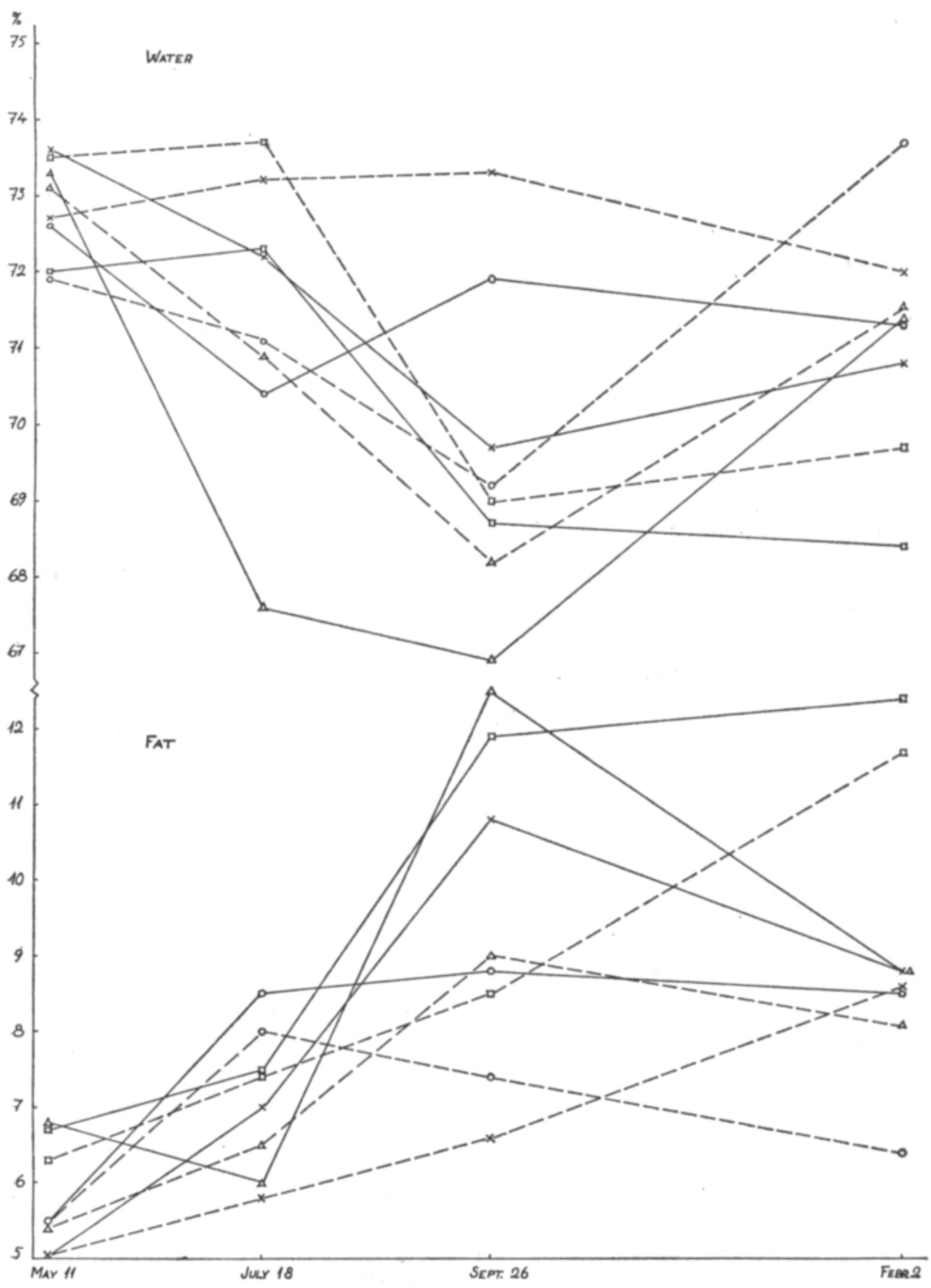

Fig. 3. Results of the approximate chemical analyses of fish.

Water and fat contents.
$x-x$
I, whole fish
$x---x$
I, gutted fish
$\square-\square$
II, whole fish
$\square---\square$
II, gutted fish
$\Delta-\Delta$
III, whole fish
$\Delta---\Delta$
III, gutted fish
0
IV, whole fish
$0--0$
IV, gutted fish 
$\mathrm{Ch}$ e m i c a l a n a ly s es. Results from the approximate analyses are presented in Figures 2 and 3 . The results revealed that there were differences between different sampling places and times of the year. Differences also existed between whole and gutted fish.

In the spring, the fat content was 1 to $2 \%$ higher in the southern sampling points (Fig. 3) and remained so throughout the experiment. There was also more fat in whole than in the gutted fish. As to protein, the content was higher in gutted than in whole fish.

Changes in the water content were reversed to those of fat, and the sum of these two components remained stable throughout the experiment. The water content was highest in the spring and decreased during the summer.

The results from the water analyses are presented in Table 2. Basically all the waters were ground waters with an acid reaction. Though they all belonged to very smooth waters (total hardness less than $4^{\circ} \mathrm{dH}$ ) rather large differences existed in the total degree of hardness. The amount of organic matter in the water was highest in all sampling places in July. The chemical composition of the cultivating water seemed to influence both the organoleptic and the bacteriological quality of the fish.

Microbiological experiments The total viable counts are presented in Fig. 4. The greatest differences between the different sampling points occurred in July. The ventral side samples had bacterial counts of $113.000 /$ gram in sampling point II, $43.750 /$ gram in IV, $9500 /$ gram in III, and $3500 /$ gram in I, respectively. The dorsal side samples were generally lower than the ventral side samples.

The coliform counts reached their maximum likewise in July (Fig. 5). In some
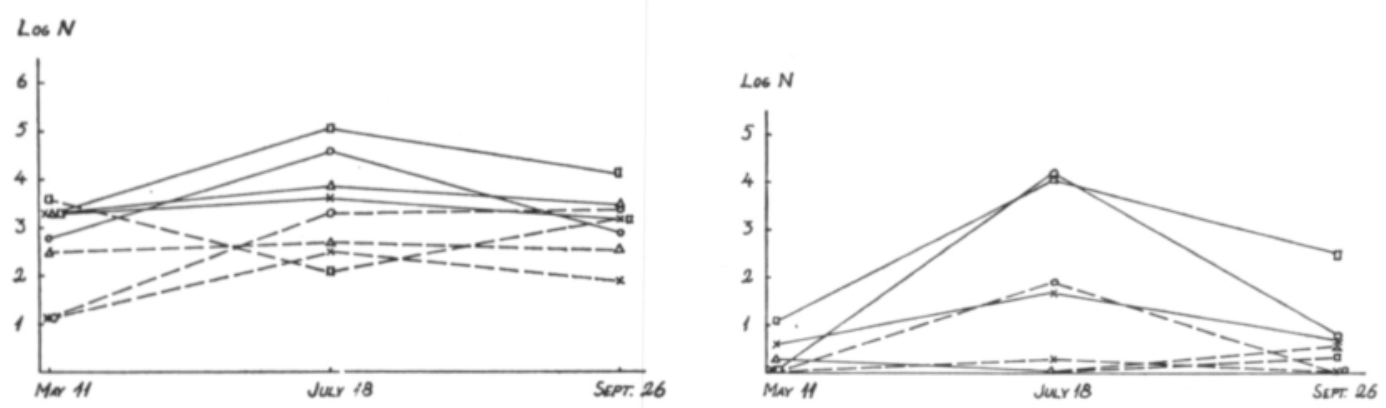

Fig. 4. Total bacterial counts of whole and gutted fish on SPC-agar.

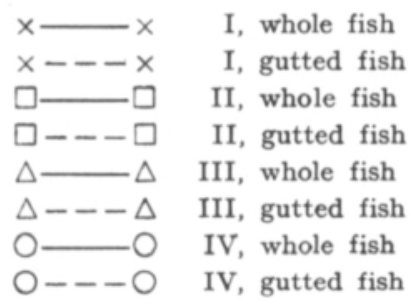

Fig. 5. Total coliforms of whole and gutted fish using the MPN-method.

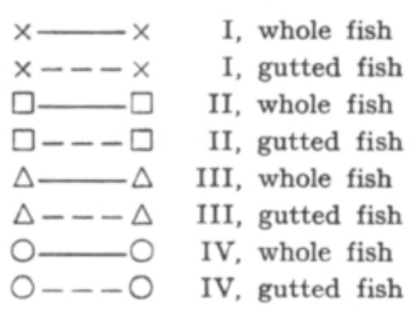


cases they were unexpectedly high but generally speaking they remained at a low level and never exceeded 100/gram in any dorsal sample.

Bacterial counts for the cultivating waters were independent from those obtained with the fish samples (Figures 4 and 5). Seasonal variations indicated that surface water had mixed with the ponds in the spring and fall. Total counts did not exceed $10^{4} /$ gram in any sample in July or in May, and in September the maximum values were between $10^{5}$ to $10^{6} /$ gram (Fig. 6). The corresponding values for total coliforms lay between 0 to $120 /$ gram (Fig. 6).

Table 2. Results of the chemical analyses from the cultivating waters.

\begin{tabular}{|c|c|c|c|c|c|c|c|}
\hline $\begin{array}{l}\text { Culti- } \\
\text { vating } \\
\text { water }\end{array}$ & \multicolumn{2}{|c|}{ Date } & $\mathrm{pH}$ & $\begin{array}{c}\text { Total } \\
\text { hard- } \\
\text { ness }{ }^{\circ} \mathrm{dH}\end{array}$ & $\begin{array}{c}\text { Color } \\
\text { Pt } \mathrm{mg} / 1\end{array}$ & $\begin{array}{l}\text { Iron } \\
\mathrm{mg} / 1\end{array}$ & $\begin{array}{l}\mathrm{KMnO}_{4}^{-} \\
\text {consump- } \\
\text { tion } \mathrm{mg} / 1\end{array}$ \\
\hline \multirow[t]{3}{*}{ I } & May & 11 & 6.05 & 0.56 & 10 & $<0.1$ & 10.1 \\
\hline & July & 18 & 6.25 & 0.80 & 12 & $<0.1$ & 25.3 \\
\hline & Sept. & 26 & 6.20 & 0.70 & 14 & $<0.1$ & 7.6 \\
\hline \multirow[t]{3}{*}{ II } & May & 11 & 6.70 & 3.14 & 46 & 0.5 & 39.2 \\
\hline & July & 18 & 6.95 & 3.70 & 56 & 0.1 & 43.0 \\
\hline & Sept. & 26 & 6.70 & 3.50 & 49 & $<0.1$ & 17.7 \\
\hline \multirow[t]{3}{*}{ III } & May & 11 & 6.60 & 1.68 & 16 & 0.1 & 13.9 \\
\hline & July & 18 & 6.80 & 1.70 & 14 & $<0.1$ & 40.4 \\
\hline & Sept. & 26 & 6.50 & 1.56 & 20 & $<0.1$ & 15.2 \\
\hline \multirow[t]{3}{*}{ IV } & May & 11 & 6.60 & 1.06 & 29 & 0.2 & 29.1 \\
\hline & July & 18 & 6.65 & 1.42 & 35 & 0.1 & 46.8 \\
\hline & Sept. & 26 & 6.20 & 1.42 & 32 & $<0.1$ & 20.2 \\
\hline
\end{tabular}

Organolepic evaluation. Table 3 shows the organoleptic quality of the test fish during summer time. The results followed the same pattern throughout the experiment and the differences between the different sampling places were quite clear. Major differences and faults were noted in structure, color and flavor. The structure and flavor faults were ascribed to the growing environment while defects in color are most likely caused by the food used.

\section{Discussion}

Although the investigation was based upon living, biological material which in all instances is very sensitive and thus heterogenous, the results indicated similar seasonal developments in all the samples and in many cases also a correlation between the different samples.

In the approximate chemical analyses the amount of protein in trout was high and never fell below $17 \%$ (Fig. 2). It was also higher in gutted than in whole fish. The amount of ash was influenced by the size of the fish and the quality and 
Table 3. Organoleptic evaluation of the tested fish

\begin{tabular}{cccccccc}
\hline $\begin{array}{l}\text { Place of } \\
\text { growth }\end{array}$ & Date & $\begin{array}{c}\text { Appear- } \\
\text { ance }\end{array}$ & $\begin{array}{c}\text { Struc- } \\
\text { ture }\end{array}$ & Color & Odor & Flavor & $\begin{array}{c}\text { Total } \\
\text { score }\end{array}$ \\
\hline \multirow{2}{*}{ 1 } & May 11 & 3 & 3 & 3.5 & 2 & $5-$ & $16+$ \\
& July 18 & 3.5 & 4 & 2.5 & 2 & 4.5 & 16.5 \\
& Sept. 26 & 3 & 3 & 4 & 2 & 4 & 16 \\
\hline \multirow{2}{*}{ II } & May 11 & 3 & 2 & 3.5 & 2 & 3.5 & 14 \\
& July 18 & 4 & 3.5 & 3 & 1.5 & 2.5 & 14.5 \\
& Sept. 26 & 1 & 3 & 2 & 2 & 2.5 & 10.5 \\
\hline \multirow{2}{*}{ III } & May 11 & 4 & 3 & 4 & 2 & 4.5 & 17.5 \\
& July 18 & 4 & 3 & 3.5 & 2 & $4+$ & $17-$ \\
& Sept. 26 & 4 & 4 & 4 & $2-$ & 3 & $17-$ \\
\hline \multirow{2}{*}{ IV } & May 11 & 2 & 3 & 2 & 2 & $3+$ & $12+$ \\
& July 18 & 1.5 & 2.5 & 3 & 2 & 3 & 12 \\
& Sept. 26 & 2 & 3 & 2 & 2 & 2.5 & 11.5 \\
\hline
\end{tabular}

quantity of food in the intestines, and no clear difference in the ash content of whole and gutted fish was observed (Fig. 2). There were no obvious seasonal variations in protein and ash.

The greatest seasonal variations occurred in the water and fat contents of the trout (Fig. 3). There were also differences between the different sampling places. In the spring the fat content was 1 to $2 \%$ higher in the south (II, III) than in the north (I, IV). The maximum values were reached in the fall, when the fat content might be as high as $12 \%$ or over in the whole fish and around $9 \%$ in the gutted fish. In place of growth III, the amount of fat increased even after it had decreased in all other sampling points. The changes in the water were reversed to those in fat but the development was not so clear as it was with the fat.

Bacteriological experiments with the fish showed that during the summer, when metabolism became more rapid, the numbers of bacteria also increased. The same phenomenon could be seen both with the total and the coliform counts (Figures 4 and 5). The ventral samples containing also intestines naturally gave higher counts than the dorsal side samples. Regarding the bacteriological results, the sampling points were found to divide into groups, one group consisting of samples II and IV with higher counts, and the other of samples I and III with distinctly lower counts. The same grouping was also noted in the organoleptic evaluation (Table 3) and these observations may have a connection with each other.

The same grouping was observed when comparing the chemical and bacteriological water analyses with the organoleptic evaluation. The amounts of iron and 
organic matter $\left(\mathrm{KMnO}_{4}\right.$-consumption) were higher in the cultivating waters II and IV (Table 2) and the situation was similar in respect of the total bacterical and coliform counts (Fig. 6).

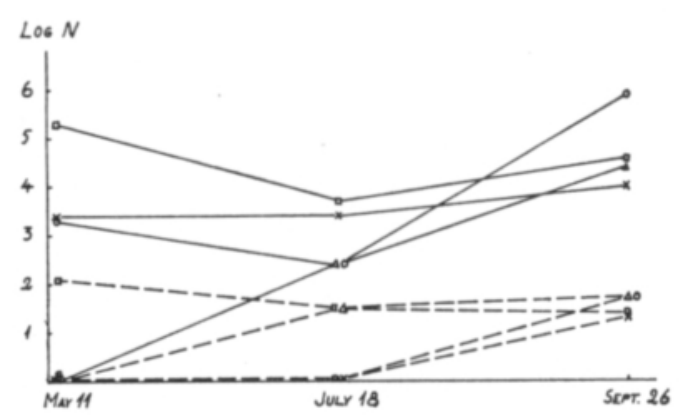

Fig. 6. Total bacterial counts on SPC-agar and total coliforms using the MPN-method in the cultivating waters.

$\begin{array}{ll}\times-\times & \text { I, total bacterial count } \\ \times---\times & \text { I, total coliforms } \\ \square-\square & \text { II, total bacterial count } \\ \square---\square & \text { II, total coliforms } \\ \triangle-\triangle & \text { III, total bacterial count } \\ \triangle---\Delta & \text { III, total coliforms } \\ \bigcirc-\bigcirc & \text { IV, total bacterial count } \\ \bigcirc---\bigcirc & \text { IV, total coliforms }\end{array}$

When comparing the bacteriological results of the fish (Figures 4 and 5) and of cultivating water (Fig. 6) it was found that the results did not correlate with each other. The counts in fish were highest in the middle of the summer when the counts in water decreased. As stated above, in the case of fish this increase depended on more rapid metabolism, while in water the decrease indicated no contamination from the surface waters, but from the water coming from the ground. On the other hand it indicated proper feeding, handling and amounts of fish in all the places of growth.

\section{Su m mary}

Seasonal variations in rainbow trout were studied in four geographically different places of growth.

Experiments were carried out in May, July, September and February. The fish was weighed and tested for approximate chemical composition, total and coliform bacteria, and organoleptic quality. Besides chemical and microbiological analyses, tests were made from the cultivating waters.

The results indicated that the fish varied according to the season and place of growth. In chemical analyses the greatest differences occurred in the amounts of water and fat. The organoleptic quality of trout seemed, however, to be mostly influenced by the places of growth.

Recognition and appreciation is extended to the Institute of Limnology, University of Helsinki, for cooperation and for making the chemical water analyses in this study. 


\section{REFERENCES}

American Public Health Association, Inc. 1958. Recommended methods for the microbial examination of foods. Albany, N.Y., U.S.A.

AOAC. 1965. Official methods of analysis. 10th ed. Assoc. Offic. Agr. Chemists, Washington D.C.

Cocks L. V. and vaN REDE, C. 1966. The laboratory handbook for oil and fat analysis. London. Del Riego, A. F. 1948. Seasonal variation in the nutritive value of the sardine (Sardinia pilchardus). Bol. Inst. Espan. Oceanog. No. 12, 15 pp. Ref. Fish as Food 1: 150, 1961, New York.

HAAse, L-W. 1954. Deutsche Einheitsverfahren zur Wasser, Abwasser und Schlammuntersuchung. Verlag Chemie G.m.b.H. Weinheim.

JAcQuot, RAymont. 1961. Organic constituents of fish and other aquatic animal foods. In Fish as Food, 1: 145, New York.

Ninivanta, F P.. Sihvola, Ritva-Lirsa and Laine, J. J. 1966. Rainbow trout (Salmo irideus) produced in Finland. I. Bacterial spoilage and amino acid composition of fresh rainbow trout during refrigerated storage. J. Sci. Agric. Soc. Finland. 38: $210-220$.

Ронja, M. S., Komulainen, Saima \& Ninnivanra, F. P. 1956. Die Fettbestimmung in Fleisch und Fleischprodukten nach dem Verfahren von Gerber. Zeitschrift für Lebensmittel Untersuchung und Forschung 103: $333-341$.

SELOST U S

TUTKIMUKSIA SUOMESSA KASVATETUSTA KIRJOLOHESTA (Salmo irideus)

III. KIRJOLOHEN VUODENAIKAISET VAIHTELUT

Jorma J. Laine, Elina Varesma ja F. P. Ninnivaara

Helsingin Yliopisto, Lihateknologian laitos

Kirjolohen vuodenaikaisia vaihteluita seurattiin neljässä kasvatuspisteessä, jotka maantieteellisesti sijaitsivat eri puolilla kirjolohen pääasiallisinta viljelysaluetta. Näytteenotto suoritettiin touko-, heină-, syys- ja helmikuussa. Kaloista suoritettiin kemiallinen kokonaisanalyysi, määritettiin bakteerien kokonaismäărä ja kokonaiskoliformipitoisuus sekä suoritettiin organoleptinen arvostelu. Tämän lisăksi seurattiin kalojen painokehitystä ja suoritettiin kemiallisia ja bakteriologisia määrityksiä kasvatusvedestä.

Tulokset osoittivat, että kalat erosivat toisistaan kasvupaikan ja vuodenajan mukaan. Kemiallisessa analyysissä vaihtelut esiintyivät erityisesti veden ja rasvan suhteissa. Sen sijaan aistinvaraisessa arvostelussa eri kasvupaikkojen aiheuttamat erot olivat selvemmät. 